$A-B[$ arley, F, M. River, forest 1916 
HARVARD UNIVERSITY.

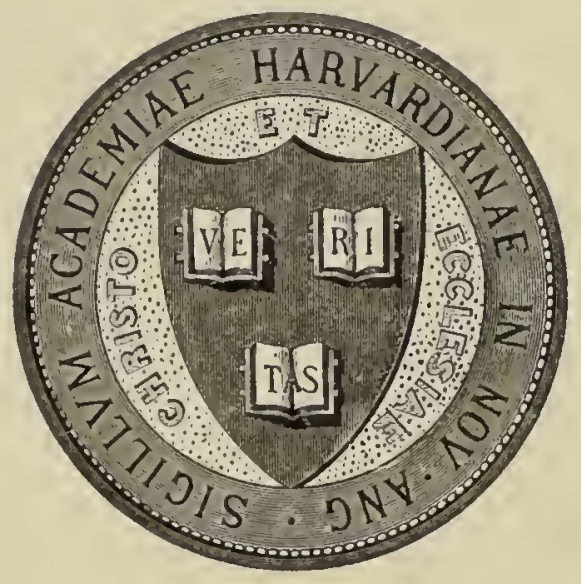

LIBRARY

OF THE

MUSEUM OF COMPARATIVE ZOÖLOGY 53.836

BEQUEST OF

WILLIAM BREWSTER

April 8, 1920. 


\title{
Birds of River, Forest and Sky
}

\author{
By Florence Merriam Ballei
}

In recalling some delightful hours once spent among the birds of McKenzie Bridge in the hear of the Cascade range, pictures of three birds, the water ouze1, the nighthawk, and the winter wren, come most vividly to mind; for they are creatures of the roaring, sparkling, glacial river, of the still, dark, coniferous forest, and above the encircling mountains, of the peaceful sunset sky.

\section{An Hour with the Dipper}

What rare memories of the Sierra Nevada and Rocky Mountains the name of dipper or water ouzel recalls! Memories of moving shadows along the dusky banks of cascaded forest brooks; memories of a gray, short-tailed bird standing alertly, questioningly, on a rock in the river as your pack train appears, and at your advance, with shortwinged flight buzzing over the dashing spray to another rock farther down the river; memories of a small gray figure on the edge of a quiet lake in a lofty glacial amphitheater.

Good hunting grounds are offered the dippers by the McKenzie river when, after rushing down from the glaciers of the Three Sisters to the middle reaches of the Cascades, it has lost most of the glacial silt that made it milky above, and after plunging headlong over rapids, spreads out green in the level stretches where jutting rocks rise above the surface and shingly bars lie along the shoals. Here, unlike the river at the foot of the glaciers where the birds are found in summer, the ouzels' hunting grounds are never closed to them, for although the water from the icy peaks warms very slowly-giving a record of $41^{\circ}$ in Junebetween rapids the current is too swift to admit of its ever freezing over.

A familiar chattering call and glimpses of a small gray form disappearing over the water now up and now down stream, together with an occasional whitewashed rock along the bank, had told us of the presence of this lovely bird which adds a charming touch of life to the wild mountain torrents of the west. A devoted habitue of the river who had wandered in happy exploration far up its forested banks told of repeatedly finding the ouzel near a cabin overlooking the river, and led me up along a woods trail to the spot. A long bar at a turn of the river was said by the friendly observers on the high bank above to be the favorite feeding ground of a pair of the birds, and whitened stones at the end of the shingle attested the fact. So, sitting down in sight of the spot, we prepared to watch the birds dine.

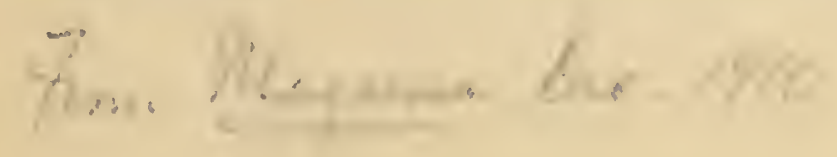


After waiting a long time for their appearance, my friend suddenly pointed tis the water on the edge of the bar, where a charming little creature, looking very bluish gray in the strong sunlight, with motionless wings was daintily paddling about in the shallow water as much at ease as if it had been a web-footed duck. Memories of ouzels that hunted and swam among the cascades of Squaw creek on Mt. Shasta returned to me at the sight. In the strong sunlight, gradations of color unseen in dark woods were observable, the head of the bird looking almost purplish, the tips of its wings and the short tail dark slate, while the lighter under parts were faintly scored.

When the ouzel started to swim, it would put its head under the water as if locating something, and then, quivering its wings, disappear altogether, coming up soon after with a long, black-shelled caddice fly larva, the shell of which, as we proved later, is a remarkable mosaic of minute stones. Known locally as grampus, the larva serves as bait for many of the visiting fishermen along this far-famed trout stream. When the bird brought up a grampus, it would shake the long shell till it finally broke open, and, pulling out the yellowish brown larva, quickly swallow it.

After bringing up and eating several of the larvae, the ouzel picked about in the submerged green mats that suggested sea-weed. Once it stood on a stone green with moss long enough to bring out the strong color contrast of the green and the gray. When walking about over the rocks it would make its droll little courtesies-dip, dip, dip-till you were constrained to speak its name-dipper.

When it had had a satisfying meal it flew across the river to a stone on the shaded bank, where, in terms of protective coloration, it perfectly pictured its background, for its gray upper parts disappeared in the dark shadow, the lighter shade of its breast toned in with the sun on the rock, and only its light-colored legs were left as slender sticks quite foreign to any bird-like suggestion. But when its profiled bill and head projected into the sun, the bird form was restored. When it moved to a branch hanging over the water and the sun touched up the branch, the plump gray form became a mere knob on the limb, so perfectly did it again picture its background. But when it dipped with the sun on it, on the instant the illusion was lost, the knob became a bird again-which, to my reading, explains the dipping, for how else could shadowy intangible family forms keep together?

After the ouzel's meal out on the bar it sat quietly for some time on the shaded bank, doubtless enjoying the spray that occasionally dashed over it from the small rapids. While it was resting, I had time to look about and observe its setting-over its head a band of low green 
alders, above, a high dark spruce wall with glimpses of mountain tops beyond, and up the river, the rushing, roaring, glacial river, patches of white rapids enclosed by converging lines of green, swiftly running water.

A metallic chatter below us made me look down just in time to see a second bird come flying in and alight in strong sunshine where, in wren-like pose, with head raised and short tail up at an angle, it stood out clear and dark. Water-wrens, the people of the camp above well called them. As we looked, the new arrival disappeared along the bank below us.

Meanwhile its mate, if as was doubtless the case they were a pair, having at last digested its grampus dinner, stretched and dipped and started out after another meal; this time hunting over the rocks along its strip of shaded shore. Back and forth it went over a short beat, hunting till it found a larva, when, flying or swimming back with it in its bill to a certain small stone that it seemed to have selected as diningroom, it would stand and shake and shake till, as I could see through my field glass, the yellowish brown larva came out of its stony case. Once, as the ouzel, in shaking, threw up its wing to keep from slipping, I caught a flash of white under wing coverts.

While we were watching the bird, a little girl from the camp above came down the bank for a pail of water, and when I urged her to be quiet exclaimed that the water-wrens paid no attention- "even when we 're hollering" up at camp. Under the bank below us the child caught sight of the second dipper, which was hunting as the first one had by the bar, going down under the water in search of grampus. But as we watched it flew across, low over the white crests of the green waves, to hunt in the shade of the opposite bank, where its mate, if it were he, was getting his supper.

At one time both birds stood on the same branch, the newcomer on the low swaying tip where the water was dashing up. Its mate had found so many larvae that its crop fairly bulged and it had to rest between feasts. The newcomer worked up along the bank, getting me excited over a dark object that for a few moments I fondly imagined was a mossy nest.

But although I had to leave for another year that most interesting of discoveries, I had seen one of the choice hunting grounds of the water ouzel in the heart of the Cascades. And right royal water sprites they seemed, to have chosen this wonderful mountain river for their home. For it was a rushing, roaring river with its "wild white horses" hurrying to the sea, the great brown boulders in its bed that tried to stay their course making them stamp the green depths of the swirling current 
and "foam and fret" till they tossed their snowy manes! What a fascinating, beautiful river, with its rushing water, its green depths, its rolling stones, its deep-voiced plunge of rocks! How the gray water sprites must love its life and sparkle! How joyously must they sing their love songs over its dashing, glistening spray!

\section{The Glowing Nighthawk Prairie}

From the upper piazza of the Log House at McKenzie Bridge we looked across the road, with its screen of low trees behind which was a mountain park, part of a strip of original prairie, now yellow with blooming St. Johnswort, and later, when the flowers had dulled, fairly twinkling with small yellow butterflies, as if the golden flowers had taken wing! At the back of the park an enclosing wall of fir carried the eye up the timbered slopes of the mountains to Horse Pasture and the bare rocky peaks of the ridge above, said to command a wonderful view of the snowy peaks of the Three Sisters at the head of the McKenzie.

Crossing the park one morning early in July, I roused a Pacific nighthawk sleeping on the ground, and the short mottled stick, unfolding long, white-banded wings, rose high in air calling Pe-uck and flying about with the expert tilting, rolling flight that characterizes the aeronaut. After that, at sunset, when the prairie floor glowed a dull orange the birds could be heard from the house and I often went out to watch them. Occasionally a few Vaux swifts or a passing flock of swallows served to give scale to the four large long-winged nighthawks which were said to be feeding on winged ants high in the sky, and which between times indulged in aeronautic feats of courtship display.

Back and forth over the prairie, calling continuously Pe-wick or $P e-u c k$, they flew, sometimes so low that I could see the white of their under parts, but generally too high to see even the wing bars, and at times so high that their long wings became mere thread lines and almost disappeared beyond the field of vision. In feeding they flew rapidly head on until presumably they came to quarry, when suddenly putting on brakes they would almost halt, and act as if snapping up insects with their widely gaping mouths.

When not absorbed in catching insects, two birds would often fly near each other in courtship play, and sometimes three flew together, as if the matter of mates were not yet settled. Frequently one of the suitors would come swooping down close to the ground or sometimes only to midair, when he spread his wings wide and the air boomed loudly through the quills - a familiar performance indicating a peculiar fondness for pyrotechnics on the part of feminine onlookers. 
One sunset, while the four long-winged birds were cavorting about the sky, as I walked across the prairie floor a soft low chorus arose from little choristers, presumably Western chipping sparrows, hidden among the glowing weeds, - a chorus so subdued and sweet that it went well with the soft evening light.

And still overhead the nighthawks beat back and forth through the sky, till their breasts grew ruddy in the sunset light, till the notch of the McKenzie leading toward the Three Sisters, earlier filled with radiant cumulus clouds, softened to rose; till, as the sun lowered, the timbered ridge at the back of the park, earlier vitalized by light and shade, had dulled, and above it the gulch of the bony lava ridge had filled with shadow, while the Saddle and Baldy had flushed with rose. Back and forth they flew till the mountains themselves grew cold and there remained only rosy streaks on Castle Rock and salmon clouds in the sky above; until at last they sailed around over the glowing field with its encircling black conifers as the evening star came out clear and bright above the golden afterglow; when down the road the light of a camp fire showed in the deepening shadows, and it seemed time to leave them to their night watch in the sky.

\section{Forest Homes of the Winter Wren}

The jolly little brown Western winter wrens, with their short tippedup tails, enliven the humid coast belt from Alaska to California and are met with at McKenzie Bridge in the heart of the Cascades, where they are as cheering as the occasional arresting red sprays of barberry.

One that we surprised when it was hunting over a fallen tree-top stopped to look at us, and when I gave a poor imitation of its te-tib' stretched up on its wiry legs in listening attitude and then bobbed on its springs. Its droll courtesy, much like that of the dipper, would certainly help to keep families together in their shadowy haunts, though both dipper and wren have acquired such a nervous habit of bobbing that they do it when it might attract the attention of unfriendly observers.

The little brown wrens who chatter and babble and pipe so gaily were met with in some of the choicest parts of the forest. On one of the fishermen's trails along the river where stumps bearing the marks of beaver teeth led to the discovery of hemlock poles dragged down the bank for their toothsome bark, and where a brotherhood of forest giants stood with the sun slanting in on their mossy sides, we surprised a family of wrenkins swarming over the bank like so many brown bumblebees; but they were quickly suppressed and spirited out of sight by their efficient parents. 
Up the river near the dippers home the wrens were found in one of the best tracts of timber in the whole region, where the wood road wound among trees five to eight feet through, their bare trunks rising a hundred to a hundred and fifty feet to the first branch; one tree that was measured after being cut reaching a hundred and seventyfive feet to the first branch.

In this stand of timber the spaces between the great boles were filled in only with cedars, from whose smooth flat leaves the sunlight seemed to slide off, and with low deciduous maples, both the vine and the Oregon, that caught the sun in their vivid green tops. In this wonderful forest the cheery bubbling song of the winter wren which crept around over stumps and logs was very grateful, harmonizing well with the patches of vivid sunlight.

In still another part of the forest, reached by a trail from the blooming prairie park where the nighthawks boomed at sunset, the friend who had shown me the hunting grounds of the water-ouzels up the river took me to see what was known as "Uncle's Woods," a stand of timber owned by an old man, one of the most respected and best loved characters of the region.

As we wandered about among the great Sitka spruces we heard the familiar voice of the little brown woodlander. Following him across a green carpet, where at each step we sank deep in the moss, we came to a big log covered with moss and ferns leading to a tree whose great base was heavily cushioned with the brownish green moss for which these humid forests are famous. The branches were hung with bulging pockets that suggested one of the canopied winter wrens' nests found in another part of the woods, a green nest made wholly of the fresh moss except for its reinforcement of springy twiglets that made an especially good frame for the round doorway. Instinctively I started to examine the bulging pockets, but as so many offered good nesting sites I soon realized that the search might be endless, and the woods were already dusky.

Meanwhile, wherever his house was hidden, the brown mite of which I had caught only aggravating glimpses, suspiciously refused to do more than answer me from the dark recesses of the woods, retreating as if to lead me away. As I peered vainly through the shadows in his direction under the high dark conifers a low deciduous tree stood out, fairly glowing green as if it had focused all the light now entering the darkening forest. Beyond it stood green-leafed alders and maples draped heavily with the golden brown moss. A wondrous forest home the little wren had chosen for himself! As we started away and once more crossed the mossy carpet the bird, so suggestively silent before, burst 
out into a low, exquisite song of happiness that could but have celebrated the escape of his loved ones.

Beyond the home of the Wrens we came to the best part of "Uncle's Woods," a stand of giant cedar. "The old man says he comes to walk among them every Sunday," my friend said gently. And no wonder, for cut off as they are from all but devout lovers of the forest, their ways are ways of quietness and in their paths are peace. Well might the old man, used to listening low to the voice of nature, stand reverently at the foot of one of these giant cedars that, with straight clean bole towering skyward confronts one with its challenge: "The place whereon thou standest is holy ground."

As we turned away from the noble brotherhood in silence and followed the narrow trail back toward the edge of the forest, the voices of the woodlanders were stilled, for the dark organ pipes stood out against the quiet light of the yellow sunset afterglow. 

 \\ Gaylord Bros.
Makers
Syracuse, N Y.
PAT. JAN. 21, 1908}

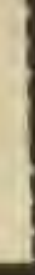

, 
